\title{
ERRATUM
}

\section{Intermittent CSF drainage and rapid EVD weaning approach after subarachnoid hemorrhage: association with fewer VP shunts and shorter length of stay}

TO THE READERSHIP: An error appeared in the article by Rao et al. (Rao SS, Chung DY, Wolcott Z, et al: Intermittent CSF drainage and rapid EVD weaning approach after subarachnoid hemorrhage: association with fewer VP shunts and shorter length of stay. J Neurosurg [epub ahead of print April 26, 2019; DOI: 10.3171/2019.1.JNS182702]).

Due to a production error, Mary M. Guanci was mistakenly included in the contributor footnote. The corrected footnote is shown below.

S.S.R. and D.Y.C. contributed equally to this work.

A.B.P. and G.A.R. contributed equally to this work. 2019.

The article has been corrected online as of June 28,

\section{Gillian Shasby}

Director of Publications

Journal of Neurosurgery Publishing Group, Charlottesville, VA

CORRESPONDING ARTICLE See pp 1583-1588.

INCLUDE WHEN CITING

Published online June 28, 2019; DOI: 10.3171/2019.5.JNS182702a.

CAANS 2020, except where prohibited by US copyright law 